\section{The effect of noni fruit (Morinda citrifolia L.) extract on interleukin 4 and interleukin 10 in Wistar rats, induced by pyrazinamide, ethambutol and levofloxacin}

\author{
Thontowi Djauhari Nur Subchi, ${ }^{1,2}$ \\ Merryana Andriani ${ }^{1}$
}

${ }^{1}$ Health Nutrition Department, Faculty of Public Health, Airlangga University, Surabaya; ${ }^{2}$ Anatomy Department, Medical Faculty of University of Muhammadiyah Malang, Indonesia

\begin{abstract}
Pyrazinamide, Ethambutol and Levofloxacin are part of the anti-tuberculosis SLD that have many side effects. This response causes an inflammatory reaction that affects pro-inflammatory cytokines interleukin 4 and interleukin 10. Morinda citrifolia $L$. produces anti-inflammatory activity that affects cytokines and provides protection against cell damage. A dose therapy was administered to wistar rats for two months, grouped in $\mathrm{K}$ - (negative control), $\mathrm{K}+$ (positive control), MI (drug + Morinda citrifolia L. extract, dose of $100 \mathrm{mg} / \mathrm{kg}$ body weight), MII (drug + noni fruit extract, dose of $200 \mathrm{mg} / \mathrm{kg}$ body weight) and MIII (drug + noni fruit extract, dose of $400 \mathrm{mg} / \mathrm{kg}$ body weight). Results were examined using Rat IL-4 and IL-10 immunoassay Quantikine ELISA kits. The ANOVA (Analysis of Variance) test results showed that there was an overall IL-4 difference $(\operatorname{sig}<0.05)$; for IL-10 there was no great difference ( $\operatorname{sig}>0.05)$; it was decrease trend was shown in MI and MII. However, by giving Morinda citrifolia $L$. extracts can significantly influence the IL-4 and IL-10, with a decreasing trend in MI and MII.
\end{abstract}

\section{Introduction}

Anti-tuberculosis second line drugs (SLD) have a lower effectiveness and a greater number of, and more severe, side effects compared with the first line drugs (FLD). Side effects caused by the SLD may be gastrointestinal (nausea, vomiting, or abdominal pain), otovestibular toxicity, arthralgia, jaundice, nephrotoxicity, hypothyroidism, and depression. ${ }^{1}$ Pyrazinamide, Ethambutol and Levofloxacin are part of the SLD, which have many side effects. ${ }^{2}$ Side effects that are mentioned, as caused after drug consumption, are gastrointestinal disorders, peripheral neuropathy (PN), hypokalemia, ototoxicity, hypothyroidism, skin disorders, and depression. The reported side effects are almost identical to those reported in Rothad's research. ${ }^{3}$

The immune system is a composite of cells, tissue, and molecules that play a role in resistance to the hazards that can be generated by various materials in the environment. ${ }^{4}$ The immune system serves to recognise, attack, and destroy various materials that endanger the health of the individual. ${ }^{5}$ The immune system plays a vital role in the human body; the decline of the immune system will facilitate microbes or harmful materials to injure the human body. However, the immune system itself can also cause cell damage, as in allergy or autoimmune cases. ${ }^{6}$

The mechanism of the immune system is divided into two, namely, cell-mediated immunity and humoral immunity. ${ }^{5}$ Cellmediated immunity means that the immune system depends on the action of the cell, in this case, the main cell being the leukocyte. Leukocytes play a major role in destroying and removing ingredients that are considered alien or harmful to the body. Meanwhile, humoral immunity means that the immune system is made up of molecules present in the blood serum. The molecule responsible for this immune system is the antibody, in which the molecule is produced by a leukocyte cell. Cell-mediated immunity and humoral immunity occur together and are synergistic in the human body; this is due to the presence of cytokines, molecules that play a major role in regulating the immune system. ${ }^{7}$

Interleukin 4 (IL-4) is a cytokine produced by Th2 cells. The cytokines are a major stimulus of $\operatorname{IgE}$ production and the development of CD4+ naive cells, stimulating B cells to differentiate into plasma cells that secrete IgE. In addition, IL-4 stimulates the differentiation of $\mathrm{T}$ naive cells into the Th2 subset. IL-4 also serves to prevent the activation of induced macrophages by IFN$\gamma$ and represents growth factor $F$ for mast cells, especially in combination with IL-3. ${ }^{6}$

Interleukin 10 (IL-10) has anti-inflammatory and immunosuppressive effects. The IL-10 cytokine inhibits the production of several other cytokines, such as IL-1, IL6, IL-8, IL-12, and TNF- $\alpha$ with activated macrophages, such as IFN-y. The production of IL-10 is derived from a sub-class of helper $\mathrm{T}$ cells; these are divided into Th1 and $\mathrm{Th} 2$, which is the differentiation of $\mathrm{Th} 0$, capable of providing anti-inflammatory effects by inhibiting Th1 activation, so that the production of proinflammatory
Correspondence: Thontowi Djauhari Nur Subchi, Doctoral Program of Public Health, Faculty of Public Health, Universitas Airlangga, Jl. Mulyorejo, Surabaya, Jawa Timur 60115, Indonesia

Tel.: +62315920948 - Fax: +62315924618.

E-mail: thontowi@yahoo.com.

Key words: Morinda citrifolia L. extract, Interleukin 4 (IL-4), Interleukin 10 (IL-10).

Acknowledgments: the authors would like to thank to Medical Faculty, University of Muhammadiyah Malang.

Contributions: the authors contributed equally

Conflict of interests: the authors declare no potential conflict of interest.

Funding: none.

Clinical trials: This research has been approved by research ethics committee of Medical Faculty, University of Muhammadiyah Malang, Malang, Indonesia.

Conference presentation: part of this paper was presented at the $3^{\text {rd }}$ International Symposium of Public Health, 2018 October 31 - November 1, Universitas Airlangga, Surabaya, Indonesia.

Dedication: the article is dedicated to Doctoral Program of Public Health, Faculty of Public Health, Universitas Airlangga, Surabaya, Indonesia; Medical Faculty, University of Muhammadiyah Malang; General Hospital of University of Muhammadiyah Malang.

Received for publication: 28 July 2019 Revision received: 9 September 2019.

Accepted for publication: 15 October 2019.

This work is licensed under a Creative Commons Attribution NonCommercial 4.0 License (CC BY-NC 4.0).

(C) Copyright: the Author(s), 2019

Licensee PAGEPress, Italy

Journal of Public Health in Africa 2019; 10(s1):1203 doi:10.4081/jphia.2019.1203

cytokines is also reduced.

One of the medicinal plants with many potential health benefits is the noni fruit, believed to have properties such as antiinflammatory, antimicrobial, antifungal, antioxidant, anti-cancer and anti-arthritis. ${ }^{8}$

\section{Materials and Methods}

The research design used was true experimental study, using a post-test-only control group design, using five sample 


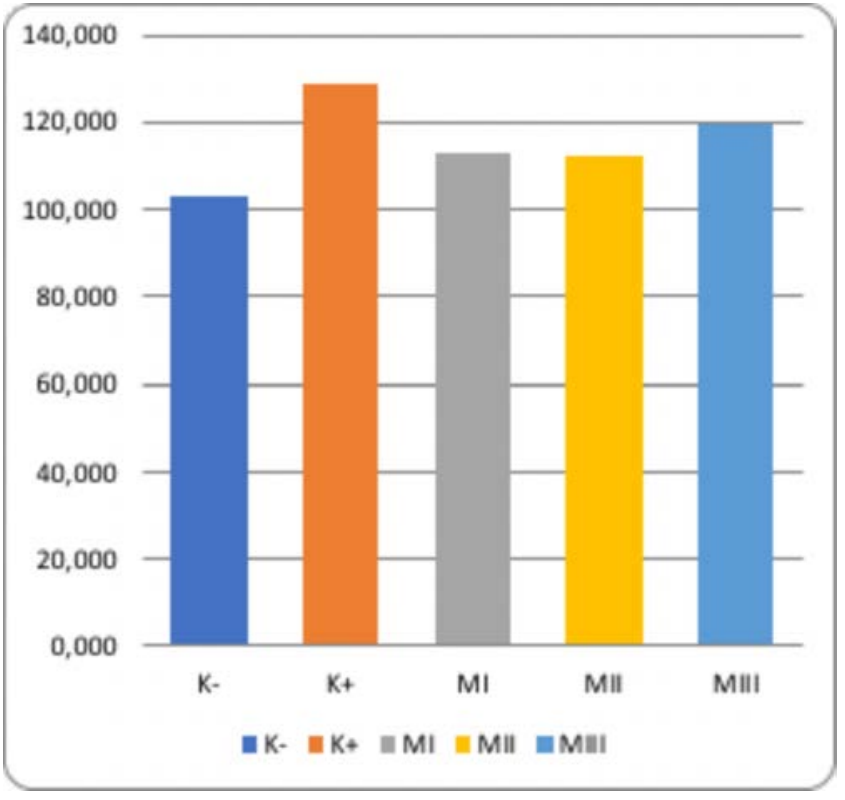

Figure 1. Interleukin 4 (IL-4).

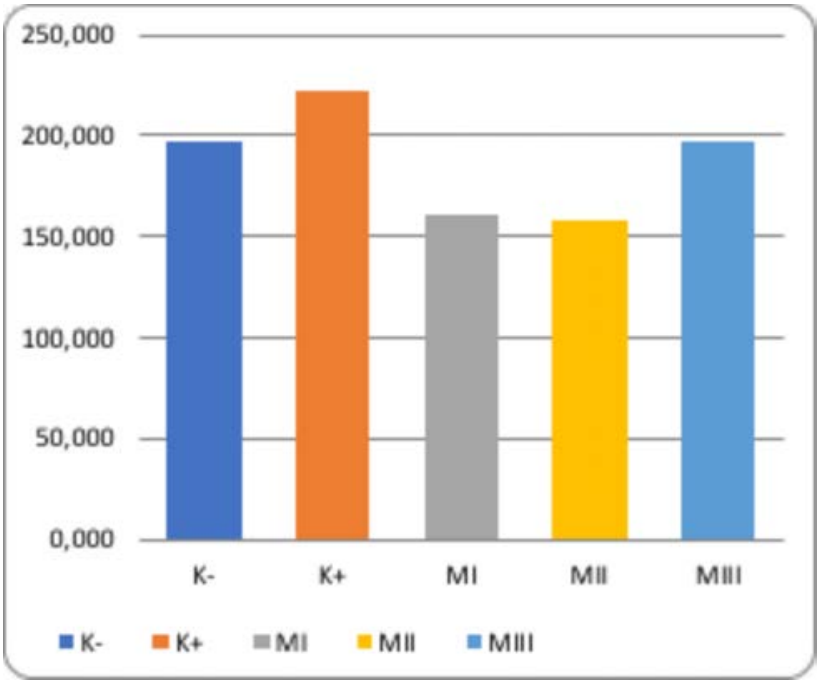

Figure 2. Interleukin 10 (IL-10). groups. The population in this study were male wistar rats (Rattus norvegicus strain wistar), with an average body weight of 200 $\mathrm{mg}$, induced with $21 \mathrm{mg} / \mathrm{kg}$ body weight of Pyrazinamide, $27 \mathrm{mg} / \mathrm{kg}$ body weight of Ethambutol and $13.5 \mathrm{mg} / \mathrm{kg}$ body weight of Levofloxacin. This dose is a normal level of therapy given to humans for 28 days, in addition, noni fruit extract was given at a dose of 100, 200 and $400 \mathrm{mg} / \mathrm{kg}$ per day for 28 days. To measure the levels of IL- 4 and IL-10, blood samples were needed from the wistar rats, measurable using the ELISA test: Rat IL-4 and IL-10 immunoassay Quantikine ELISA kit. One-way ANOVA will be used to prove a significant difference between the control and the group receiving noni fruit extract; ANOVA test results are said to have significant differences if there is a significant ( $\mathrm{sig}$ ) result of $<0.05$.

\section{Results and Discussion}

Based on Figure 1, it is known that the highest value of IL-4 lies in the $\mathrm{K}+$ group, while the smallest average lies in the $\mathrm{K}$ group. ANOVA test results showed that there was overall IL-4 difference (sig $<0.05$ ). Based on Figure 2, it is known that the highest value of IL-10 lies in the $\mathrm{K}+$ group, while the smallest mean lies in the MII group. The ANOVA test results showed that there was no overall IL-10 difference $(\mathrm{sig}>0.05)$.

Based on the above data, the adminis- tration of the noni extract showed an effect on IL-4, wherein the noni fruit extract can decrease the pro-inflammatory cytokine IL4 , so that the side effects of the three drugs can be reduced. Regarding IL-10, noni fruit extract does not have a large effect, but a decreasing trend is seen from administering it. IL-4 is a pleiotropic cytokine secreted by $\mathrm{T}$ cells that have been activated into $\mathrm{TH} 2$ cells; it plays a dominant role in the immune system and is an important factor in the development of hypersensitivity. ${ }^{9}$ IL-10 is a cytokine that is widely secreted by monocytes; it has a pleiotropic effect on the immune system and inflammation, and is known for its ability to inhibit the activation and effector functions of $\mathrm{T}$ cells, monocytes and macrophages. ${ }^{10}$ The routine function of IL-10 seems to be primarily to inhibit or negate inflammatory responses. ${ }^{11}$ IL-4 and IL-10 have different anti-inflammatory mechanisms. It is possible that IL-10 needs co-factors in order to act as an anti-inflammatory mediator. ${ }^{12}$

IL-10, as an anti-inflammatory cytokine, can help suppress inflammation resulting from all three drugs.

\section{Conclusions}

Noni fruit extract can significantly influence the IL-4 and the IL-10, with a decreasing trend in MI and MII. This is because, in this study, the dose given was therapeutic, given over an eight-week period only.

\section{References}

1. Rathod KB, Borkar MS, Lamb AR, et al. Adverse events among patients of multi drug resistant tuberculosis receiving second line anti-TB treatment. International Journal of Scientific Reports 2015;6:253-257.

2. Akshata J, Chakrabarthy A. Management of multidrug resistant tuberculosis (MDR-TB)-Monitoring is the key to successful outcome. Egyptian Journal of Chest Diseases and Tuberculosis 2016;65:447-450.

3. El Din M, El Maraghy A, Hay A. Adverse reactions among patients being treated for multi-drug resistant tuberculosis at Abbassia Chest Hospital. Egyptian Journal of Chest Diseases and Tuberculosis 2015;64:939-952.

4. Baratawidjaja KG, Rengganis I. Imunologidasar (10th Ed). Jakarta: Badan Penerbit Fakultas Kedokteran Universitas Indonesia; 2012.

5. Mak TW, Saunders ME, Jett BD. Primer to the Immune Response. San Diego: Elsevier; 2014.

6. Kumar V, Abbas AK, Aster JC. Buku Ajar Patologi Robbin edisi, (9th Ed). Singapore: Elsevier Inc.; 2015.

7. Sivangala R, Sumanlatha G. Cytokines that mediate and regulate immune responses. In G. S. Latha, Innovative Immunology:1-26. Hyderabad: Austin Publishing Group; 2015.

8. Serafini MR, de Oliveira BE, de Almeida BF, et al. Anti-inflammatory 
property and redox profile of the leaves extract from Morindacitrifolia, Academic Journal 2015;9(24):693-701.

9. Tanaka, T., Narazaki, M., Kishimoto, T. IL-6 in inflammation, immunity, and disease. Cold Spring Harbor Perspectives in Biology 2014;6(10):a016295. Available from: https://doi.org/10.1101/cshperspect.a01 6295. Accessed on: 10 March 2018.
10. Moore KW, de Waal MR, Coffman RL, et al. Interleukin-10 and the interleukin10 receptor. Annual Review of Immunology 2001;19(1):683-765.

11. Beebe AM, Cua DJ, Waal MR. The Role of Interleukin-10 in autoimmune disease: systemic lupus erythematosus (SLE) and multiple sclerosis (MS). Cytokine \& Growth Factor Reviews 2002;13(4-5):403-412.
12. Lee SW, Hong YS, Chun CM, et al. Antiinflammatory effects of $\mathrm{IL}-4$ and $\mathrm{IL}-10$ on human polymorphonuclear leukocytes. Journal of Korean Medical Science 2002;17(1):7-14. Available from: https://doi.org/10.3346/jkms . 2002.17.1.7. Accessed on: 10 March 2018. 